\title{
Lessons from the dark side
}

What role did German scientists and their funding organization play in supporting Nazi policies during 1933-45? In a bid to find out, Germany's research council, the DFG, sponsored a seven-year investigation into its own history that ended last month. One of the historians who led the study, Ulrich Herbert of the University of Freiburg, discusses the findings.

\section{What sources were made available to you?}

We were given access to all the DFG files, right back to the start of the society in 1920 . These files were fundamental because we wanted to analyse what the scientists themselves requested funding for. Then we were able to look at what they did with the money they got.

\section{What did you discover during the investigation?}

We didn't find out about any sensational new crimes - and we weren't expecting to. Most of the immense dark crimes we know about today, such as the euthanasia programmes and human experimentation, were discussed after the Nuremberg trials that immediately followed the war. But we learnt how exquisitely closely 'normal' professors - not just the mad Nazi types - aligned their goals with the policies of the Nazi regime. Grant applications showed, for example, how many professors took part in developing plans for expansion to the east after Germany won the war (as they assumed). Plans that would have killed or enslaved more than 30 million people.

\section{Did the effects persist beyond 1945?}

Because we covered the period from 1920 to 1970, not just the specific Nazi years, we were able to document the impact on the German intelligentsia of the nationalism that arose after the First World War. We saw that it didn't end in 1945, but continued into the early 1960s, when there was a change of generation. We also saw that the expulsion of Jews and democrats from the universities nearly a quarter of all professors - stymied the development of modern biology. After the war, molecular and cell biology took off in other countries, but Germany was left behind. On the other hand some subjects, such as cancer research, were unhindered. In fact, some very good science was funded by the Nazis - leaving Germany in good shape.

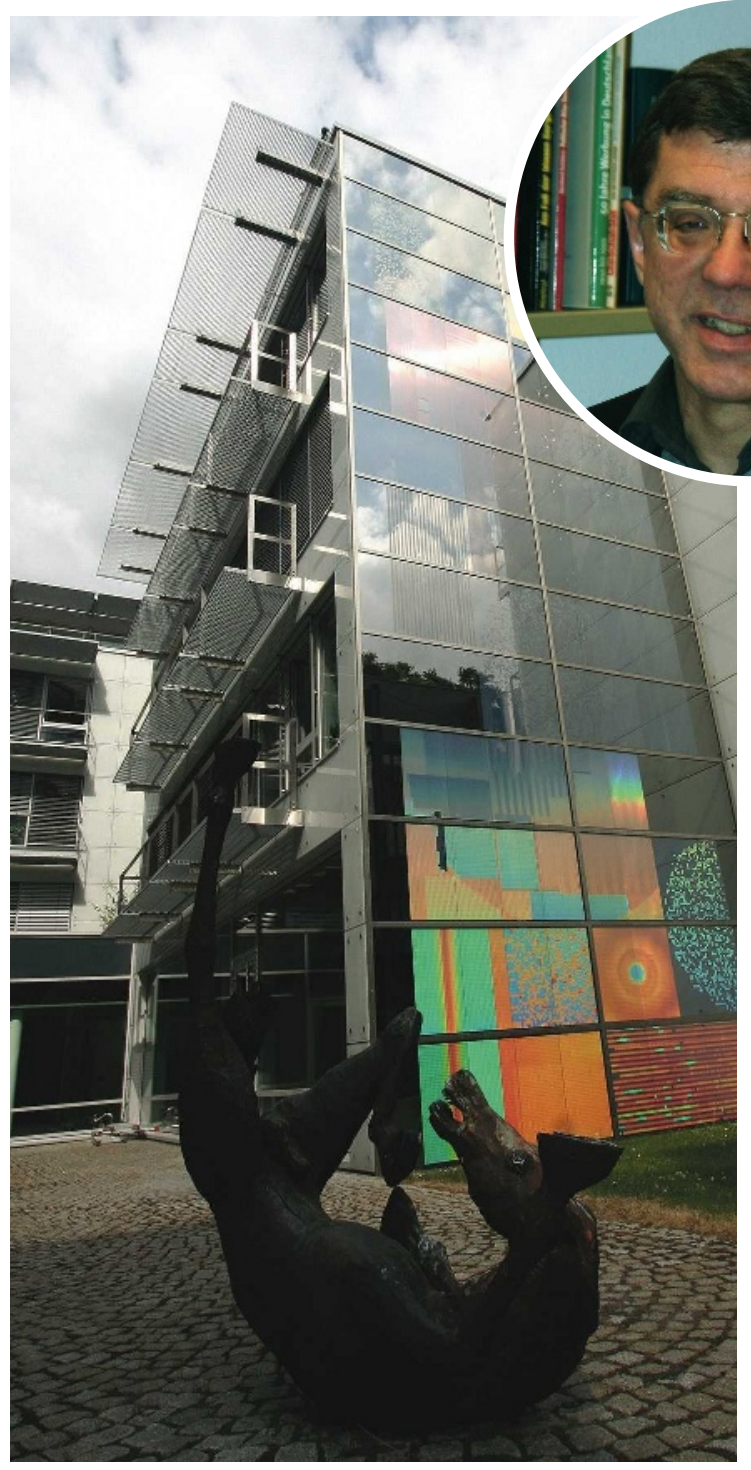

Ulrich Herbert (inset) has examined the DFG's murky past.

\section{What did you learn that may have relevance today?}

The prevailing political view in Germany is that federalism is a better defence against totalitarianism than centralized power. The 1949 German constitution introduced extensive federalism for this very reason. But we saw that the behaviour of scientists at universities, which were decentralized in Nazi times, was no different from scientists working at the institutes of the centralized
Max Planck Society, [which historians investigated a few years ago]. So we can't say that federalism alone is the answer to all evils.

Universities ended up colluding with the regime because the conservative professors who were able to continue working there agreed, like the general population, with most Nazi policies. There was no organized opposition to the views and no public debate of different positions. So although euthanasia of the mentally deficient was debated in many countries in the 1920s and 1930 s, it was not only put into practice but accelerated in Germany. Having learnt that eliminating pluralism leads to radicalization, it's no wonder that Germany is cautious about things such as stem-cell research. We've experienced how things can go wrong in this sphere. Maybe we can be proud of the constant public debates we have, even though they seem to slow things down.

\section{Do you think that other countries - Russia or China, for example — should undertake similar investigations?}

I'm a bit shy, as a German, to say that others should learn from what Germany has done. But I think all countries with a totalitarian past might similarly gain from considering the history of their institutions - particularly their academic systems, where so much collaboration occurs. It's good to know the dark side of one's history - self-confidence is deepened if we are more aware of our own mistakes. It is also important to know if there are continuities - we found that many colluders made good scientific careers in our new democracy. Of course each nation has to decide for itself, but I think the exercise is very fruitful.

Interview by Alison Abbott 